\title{
MODEL SOSIAL-EKONOMI DAN KETAHANAN PANGAN RUMAH TANGGA DI INDONESIA
}

\author{
SOCIO-ECONOMIC MODEL AND HOUSEHOLDS'FOOD SECURITY \\ IN INDONESIA
}

\author{
Laksmi Yustika Devi $^{*}$, Yuni Andari ${ }^{1}$, Latri Wihastuti ${ }^{1}$, RY Kun Haribowo ${ }^{1}$ \\ ${ }^{1}$ Departemen Ekonomika dan Bisnis, Sekolah Vokasi, Universitas Gadjah Mada \\ *laksmiydevi@ugm.ac.id
}

\begin{abstract}
Abstrak
Ketahanan pangan adalah salah satu prioritas pembangunan dalam Rencana Kerja Pemerintah (RKP). Perumusan kebijakan tentang implementasi ketahanan pangan harus mampu memberikan output yang dapat mengarah pada stabilisasi ketersediaan pangan berdasarkan swasembada, serta meningkatkan kemudahan akses dan kemampuan mengakses pangan. Penelitian ini bermaksud untuk menganalisis faktor-faktor sosial ekonomi yang mempengaruhi ketahanan pangan di Indonesia. Data yang digunakan adalah data tingkat rumah tangga dari Indonesian Family Life Survey (IFLS) kelima dengan jumlah rumah tangga yang diperkirakan sebanyak 9.819 rumah tangga. Penelitian ini menggunakan regresi logistik sebagai metode estimasi, dengan variabel dependen yaitu ketahanan pangan yang dihitung berdasarkan food consumption score (FCS). Sementara, variabel independen yang digunakan adalah: (1) profil kepala rumah tangga yang meliputi usia, jenis kelamin, status perkawinan, tingkat pendidikan; (2) faktor kualitatif yang meliputi jenis pekerjaan kepala rumah tangga, bahan bakar utama untuk memasak, ketersediaan toilet, listrik, dan sumber air di dalam rumah; dan (3) lokasi rumah tangga (perkotaan atau perdesaan). Hasil penelitian menunjukkan bahwa faktor-faktor yang mempengaruhi ketahanan pangan rumah tangga adalah aspek sanitasi (keberadaan toilet dan sumber air di dalam rumah), penggunaan bahan bakar utama untuk memasak, lokasi rumah tangga, serta usia, status, tingkat pendidikan dan jenis mata pencaharian kepala rumah tangga.
\end{abstract}

Kata kunci: ketahanan pangan, rumah tangga, IFLS, faktor sosial ekonomi, Indonesia

Klasifikasi JEL: I31, Q18, R20

\begin{abstract}
Food security is one of the development priorities in the Government Work Plan (RKP). The formulation of policies regarding the implementation of food security must provide an output that can stabilize food availability based on self-sufficiency and increase ease and ability to access food. This study intends to analyze the socio-economic factors affecting food security in Indonesia. The data used is household-level data from the fifth Indonesian Family Life Survey (IFLS5) covering 9.819 households. This study uses logistic regression as an estimation method with the dependent variable, namely food security, calculated based on the food consumption score (FCS). Meanwhile, the independent variables are: (1) the profile of the head of the household which includes age, gender, marital status, level of education; (2) qualitative factors which include the type of work of the head of the household, the main fuel for cooking, the availability of toilet, electricity, and water sources in the house; and (3) the location of the households (urban or rural areas). The results show that factors influencing household food security are sanitation aspects (the presence of toilet and water sources inside the house), the use of the main fuel for cooking, the location of the household, as well as the age, marital status, level of education and the type of livelihood of the head of the household.
\end{abstract}

Keywords: food security, household, IFLS, socio-economic factors, Indonesia

JEL Classification: $131, Q 18, R 20$ 


\section{PENDAHULUAN}

Berdasarkan Global Food Security Index (GFSI) 2018, ketahanan pangan Indonesia berada di posisi 65, di bawah Singapura (1), Malaysia (40), Thailand (54), dan Vietnam (62). Namun demikian, posisi Indonesia tersebut meningkat bila dibandingkan dengan posisi Indonesia di tahun 2017, yaitu di peringkat 69 (The Economist Group, 2018).

GFSI menilai ketahanan pangan negaranegara di dunia dengan menggunakan beberapa indikator, yaitu keterjangkauan (affordability), ketersediaan (availability), kualitas dan keamanan (quality and safety) dan sumber daya dan ketahanan alam (natural resources and resilience). Indikator-indikator tersebut masih dibagi lagi ke dalam beberapa sub indikator. Tabel 1 berikut menggambarkan kondisi Indonesia di antara negara-negara Asia Tenggara lainnya berdasarkan beberapa sub indikator keterjangkauan, ketersediaan, kualitas dan keamanan pangan. Dalam hal porsi konsumsi pangan dalam pengeluaran rumah tangga,
Indonesia hanya lebih baik dari Vietnam, yaitu sebesar 32,8 persen. Namun, angka ini masih jauh di atas Singapura yang memiliki porsi konsumsi pangan dalam pengeluaran rumah tangga hanya sebesar 6,9 persen. Mulyanto (2005) menyatakan bahwa semakin tinggi pengeluaran untuk pangan, berarti semakin kurang kesejahteraan rumah tangga yang bersangkutan. Sebaliknya, semakin kecil pangsa pengeluaran pangan maka rumah tangga tersebut semakin sejahtera.

Tabel 1 juga memberikan informasi bahwa proporsi populasi di bawah garis kemiskinan Indonesia merupakan yang terbesar dibandingkan negara-negara lainnya. Kemiskinan akan mempengaruhi keterjangkauan masyarakat untuk mengakses pangan. Dalam hal ketersediaan pangan, Indonesia masih di atas Vietnam dan tidak jauh dari angka kkal/kapita/hari yang dimiliki Thailand. Sementara untuk diversifikasi diet (pangan), Indonesia memiliki angka yang paling kecil. Hal ini dapat diartikan kurang beragamnya pola konsumsi pangan penduduk Indonesia.

Tabel 1. Keterjangkauan, Ketersediaan, Kualitas dan Keamanan Pangan di Beberapa Negara Asia Tenggara, 2018

\begin{tabular}{|c|c|c|c|c|c|c|}
\hline \multicolumn{2}{|c|}{ Keterjangkauan Pangan } & \multicolumn{5}{|l|}{ Negara } \\
\hline Sub indikator & Unit & Indonesia & Singapura & Malaysia & Thailand & Vietnam \\
\hline PDB per kapita & US\$ per PPP/kapita & $12.440,6$ & $96.556,3$ & 29.450 & $18.060,8$ & $6,780.0$ \\
\hline $\begin{array}{l}\text { Proporsi populasi } \\
\text { di bawah garis } \\
\text { kemiskinan }\end{array}$ & $\begin{array}{l}\% \text { populasi den- } \\
\text { gan penghasilan di } \\
\text { bawah } \$ 3,20 \text { per } \\
\text { hari }(2011 \mathrm{PPP})\end{array}$ & 8,3 & 0,0 & 0,6 & 0,1 & 3,0 \\
\hline $\begin{array}{l}\text { Porsi konsumsi } \\
\text { pangan dalam } \\
\text { pengeluaran } \\
\text { rumah tangga }\end{array}$ & $\begin{array}{l}\% \text { dari total pengelu- } \\
\text { aran rumah tangga }\end{array}$ & 32,8 & 6,9 & 21 & 24.1 & 36.1 \\
\hline $\begin{array}{l}\text { Ketersediaan } \\
\text { program ketah- } \\
\text { anan pangan }\end{array}$ & $\begin{array}{l}\text { Penilaian kualitatif } \\
(0-4)\end{array}$ & 3,0 & 4,0 & 3,0 & 3,0 & 3,0 \\
\hline \multicolumn{2}{|c|}{ Ketersediaan Pangan } & \multicolumn{5}{|l|}{ Negara } \\
\hline Sub indikator & Unit & Indonesia & Singapura & Malaysia & Thailand & Vietnam \\
\hline $\begin{array}{l}\text { Ketersediaan } \\
\text { pangan rata-rata }\end{array}$ & kkal/kapita/hari & 2.777 & 3.051 & 2.916 & 2.784 & 2.745 \\
\hline \multicolumn{2}{|c|}{ Kualitas dan Keamanan Pangan } & \multicolumn{5}{|l|}{ Negara } \\
\hline Sub indikator & Unit & Indonesia & Singapura & Malaysia & Thailand & Vietnam \\
\hline Diversifikasi diet & $\%$ & 31 & 56,5 & 56 & 51 & 42 \\
\hline
\end{tabular}

Sumber: GFSI, 2018 
Di Indonesia, disparitas ketahanan pangan dapat dilihat dari proporsi penduduk dengan asupan kalori minimum di bawah $1400 \mathrm{kkal} /$ kapita/hari. Secara keseluruhan, nilai persentase untuk Indonesia semakin kecil dari tahun 2015-2017, yang menandakan bahwa ketahanan pangan semakin meningkat. Namun, masih banyak provinsi yang memiliki nilai proporsi penduduk dengan asupan kalori minimum di bawah 1400 kkal/kapita/hari. Pada tahun 2017, masih terdapat 19 provinsi dari total 34 provinsi atau sebesar 55,9 persen yang masih memiliki nilai proporsi penduduk dengan asupan kalori minimum di bawah $1400 \mathrm{kkal} /$ kapita/hari di bawah rata-rata nasional. Di tahun yang sama, provinsi DI Yogyakarta dan Papua adalah provinsi dengan nilai proporsi terendah (2,15 persen) dan tertinggi (24,8 persen). Dengan demikian, masih terdapat disparitas ketahanan pangan yang tinggi antar provinsi di Indonesia.

Menurut data GFSI, ketersediaan pangan rata-rata Indonesia di tahun 2017 adalah 2.777 $\mathrm{kkal} / \mathrm{kapita} / \mathrm{hari}$, sementara garis ketahanan pangan yang digunakan oleh BPS adalah 1.400 kkal/kapita/hari. Smith \& Haddad (2000) menyatakan bahwa kerawanan pangan tidak memiliki keterkaitan kuat dengan ketersediaan pangan. Dengan demikian, kelebihan ketersediaan pangan nasional tidak berarti menunjukan bahwa Indonesia telah bebas dari kerawanan pangan. Ariani (2004) juga mengemukakan bahwa ketersediaan pangan merupakan prasyarat penting tetapi belum mencukupi (necessary but not sufficient) bagi keberlanjutan konsumsi pangan karena masih banyak variabel yang berpengaruh untuk mencapai ketahanan pangan tingkat daerah dan rumah tangga. Lebih lanjut, Damanik (2016) membuktikan bahwa tidak ada hubungan kausalitas antara ketahanan pangan dengan kemiskinan di Indonesia. Artinya, ketahanan pangan tidak menyebabkan kemiskinan di Indonesia dan kemiskinan juga tidak menyebabkan melemahnya ketahanan pangan di Indonesia. Tajerin, Sastrawidjaja, \& Yusuf(2017) menyatakan bahwa tidak ada indikator tunggal yang dapat merangkum status ketahanan pangan rumah tangga secara keseluruhan karena konsep ketahanan pangan bersifat multidimensial. Hal ini berlaku baik bagi rumah tangga pertanian maupun non pertanian.
Oleh karena itu, penelitian ini bermaksud untuk menganalisis faktor-faktor yang mempengaruhi ketahanan pangan rumah tangga di Indonesia, khususnya faktor-faktor sosial ekonomi dengan menggunakan data Indonesian Family Life Survey 5 (IFLS5). Dengan penggunaan data IFLS5 di tingkat rumah tangga, diharapkan hasil dari penelitian ini dapat menjadi bahan pertimbangan berbasis data nasional bagi pembuat kebijakan ketahanan pangan, karena penelitian-penelitian sejenis sebelumnya, umumnya menggunakan data survei dengan lokasi terbatas (Tajerin, et al. 2017; Zani, Saediman, Abdullah, Daud \& Yunus, 2019).

\section{TINJAUAN PUSTAKA}

Ketahanan pangan nasional dapat diartikan sebagai kemandirian dalam penyediaan pangan (Pinstrup-Andersen, 2009). Menurut Life Science Research Organization (LSRO) ketahanan pangan adalah tersedianya akses dimana semua orang di setiap saat mendapatkan makanan yang cukup untuk kehidupan yang aktif dan sehat dan minimal mencakup: a) ketersediaan makanan yang aman dan memadai secara nutrisi, dan b) terjaminnya kemampuan untuk mendapatkan makanan yang dapat diterima secara sosial (sebagai contoh: tanpa menggunakan persediaan makanan darurat, memulung, mencuri, dan strategi mengatasi lainnya). Sebaliknya, kerawanan pangan adalah terbatasnya atau tidakpastinya ketersediaan makanan yang bergizi memadai dan aman atau kemampuan untuk memperoleh makanan dengan cara yang dapat diterima secara sosial (Radimer, 2002). Konsep kerawanan pangan seperti yang dipikirkan di Amerika Serikat ini tidak hanya mencakup kurangnya ketersediaan, akses, dan pemanfaatan atau penggunaan makanan (misalnya, persiapan makanan dan distribusi makanan di dalam rumah tangga), tetapi juga persepsi (misalnya, bahwa makanan tidak cukup, tidak memadai, tidak dapat diterima, tidak pasti, atau tidak berkelanjutan) (Wolfe \& Frongillo, 2001).

Vhurumuku (2014) menambahkan bahwa ketahanan pangan dapat diukur dari dua sisi, yaitu keragaman makanan dan frekuensi makan (dietary diversity dan food frequency) serta perilaku konsumsi (consumption behaviors). Keragaman makanan dan frekuensi makan memiliki beberapa 
indikator: 1) skor konsumsi makanan (food consumption score) yang mengukur asupan kalori dan kualitas makanan di tingkat rumah tangga, 2) skala keragaman makanan rumah tangga (household dietary diversity scale), 3) kurang gizi (undernourishment) dan 4) proporsi pengeluaran rumah tangga untuk makanan (spending on food). Perilaku konsumsi dapat diukur dengan: 1) coping strategies index yaitu indeks untuk mengukur apa yang akan dilakukan orang bila mereka tidak dapat mengakses cukup makanan, 2) skala akses dan kerawanan pangan rumah tangga (household food insecurity and access scale), 3) skala kelaparan rumah tangga (the household hunger scale), dan 4) pengukuran mandiri terhadap kerawanan pangan (self-assessed measure of food security).

Di tingkat rumah tangga, Gundersen, Kreider, \& Pepper (2011) mengelompokkan tingkat ketahanan pangan sebagai berikut: 1) Ketahanan pangan, yaitu kondisi saat seluruh anggota keluarga di setiap waktu mampu mengakses jumlah pangan yang cukup untuk dapat beraktivitas dengan baik dan menjaga hidup sehat; 2) Ketahanan pangan rendah, yaitu kondisi saat salah satu anggota keluarga merasa tidak yakin atau tidak mampu untuk memperoleh pangan yang cukup karena keterbatasan dana dan sumber daya yang lain; serta 3) Ketahanan pangan yang sangat rendah, yaitu kondisi saat satu atau lebih anggota rumah tangga kelaparan, setidaknya beberapa waktu sepanjang tahun, karena mereka tidak mampu membeli makanan yang cukup. Kategori (2) dan (3) dapat digolongkan sebagai kondisi ketidakamanan (kerawanan) pangan.

Pendapat bahwa kondisi rumah tangga memiliki peranan penting dalam ketahanan pangan rumah tangga juga didukung, di antaranya, oleh Abdullah et al., 2019; Abu \& Soom, 2016; Ahmed, Ying, Bashir, Abid, \& Zulfiqar, 2017; Dharmasena, Bessler, \& Todd, 2016; Grobler, 2016; Lestari \& Sarana, 2018; Maharjan \& Joshi, 2011; Mustapha, Kamaruddin, \& Dewi, 2018; Rose, Gundersen, \& Oliveira, 1998; Sulemana, Bugri Anarfo, \& Quartey, 2019. Semua penelitian tersebut menyimpulkan bahwa terdapat perbedaan kondisi sosial ekonomi pada rumah tangga aman pangan dan rumah tangga rawan pangan.
Cafiero, Melgar-Quiñonez, Ballard, \& Kepple (2014) melakukan penilaian terhadap beberapa indikator ketahanan pangan yang mereka golongkan dalam dua kategori: 1) kategori berdasarkan konsep kecukupan konsumsi pangan (food consumption adequacy), dan 2) kategori berdasarkan respon pengalaman yang umumnya banyak digunakan di berbagai kebudayaan. (experience-based food insecurity scales). Penilaian indikator dilakukan berdasarkan dua hal, yaitu validitas dan realibilitas.

Cafiero et al. (2014) menyatakan bahwa, dari beberapa indikator ketahanan pangan yang tersedia saat ini, indikator yang paling valid dan dapat dipercaya adalah indikator dari The Food Insecurity Experience Scale/FIES yang dikembangkan oleh proyek the Voices of the Hungry (VoH). FIES dilakukan dengan survei berdasarkan 8 pertanyaan sebagai berikut: "Dalam 12 bulan terakhir, apakah ada saat, karena kekurangan uang ataupun sumber daya yang lain: 1) Anda merasa khawatir tidak memiliki cukup makanan?; 2) Anda tidak dapat makan makanan yang sehat dan bergizi?;3) Anda hanya makan beberapa jenis makanan saja?; 4) Anda harus melewatkan waktu makan?; 5) Anda makan lebih sedikit daripada yang seharusnya?; 6) Rumah tangga Anda kehabisan makanan?; 7) Anda merasa lapar tetapi tidak makan?; serta 7) Anda melewatkan 1 hari dengan tidak makan?" Jawaban dari kedelapan pertanyaan tersebut kemudian akan dibuat skala seperti pada Gambar 1.

Namun demikian, indikator ketahanan pangan yang dianggap paling sesuai dan sederhana dalam mengukur konsumsi pangan rumah tangga adalah indikator dari World Food Program, yaitu Food Consumption Score (FCS) (Tiwari, Skoufias \& Sherpa, 2013; Cafiero et al., 2014; INDDEX Project, 2018; Isaura, Chen \& Yang, 2018). Perhitungan skor FCS dilakukan dengan menggunakan data keragaman dan frekuensi kelompok makanan yang dikonsumsi oleh suatu rumah tangga selama tujuh hari sebelumnya. Data ini kemudian diberikan bobot menurut nilai gizi relatif dari kelompok makanan yang dikonsumsi. Misalnya, kelompok pangan kaya gizi, seperti produk hewani, diberi bobot lebih besar daripada kelompok pangan miskin gizi, seperti umbi- 


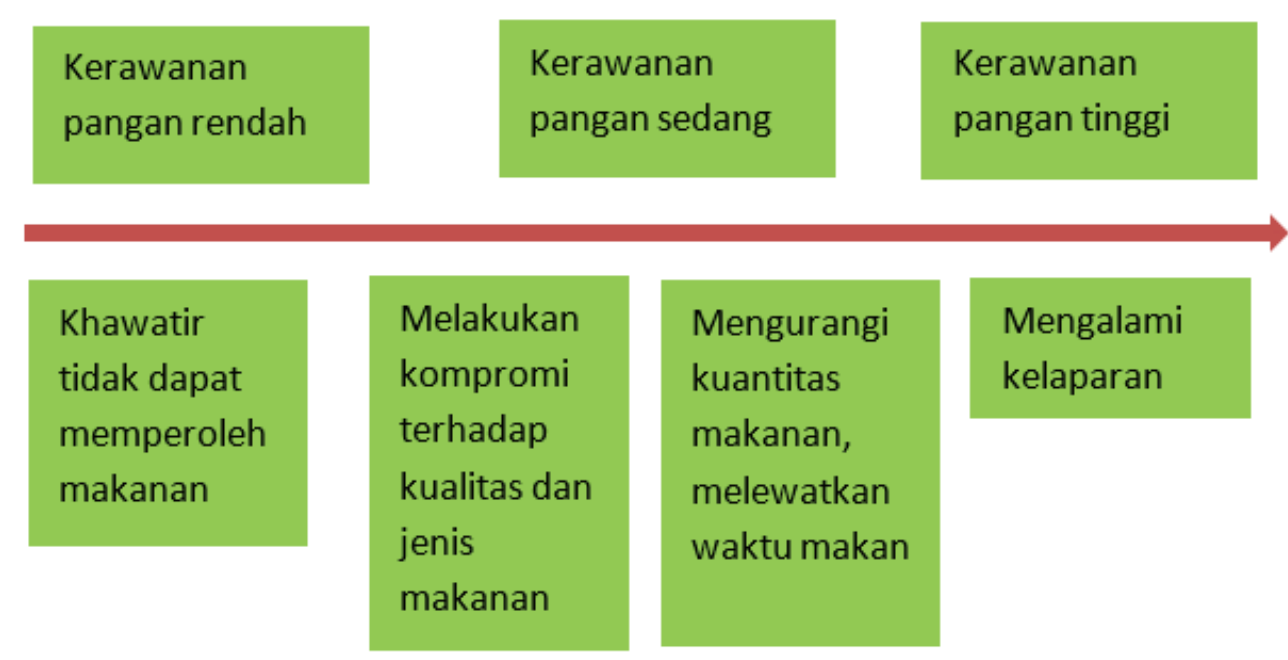

Gambar 1. Skala Kerawanan Pangan berdasarkan FIES

Sumber: FAO, 2017

umbian (INDDEX Project, 2018). Kelompok makanan beserta pembobotannya termuat dalam Tabel 2. Skor setiap kelompok makanan kemudian dijumlahkan untuk didapatkan skor akhir. Suatu rumah tangga berada dalam kondisi rentan (poor) bila skor FCS akhir adalah 0-21; dalam garis batas (borderline) bila skor FCS akhir adalah 21.5-35; serta aman (acceptable) bila skor FCS lebih dari 35 (INDDEX Project, 2018).

Tabel 2. Kelompok Makanan dan Pembobotannya Menurut FCS

\begin{tabular}{ll}
\hline Kelompok Makanan & Bobot \\
\hline $\begin{array}{l}\text { Makanan pokok (main } \\
\text { staples) }\end{array}$ & 2 \\
\hline Kacang-kacangan (pulses) & 3 \\
\hline $\begin{array}{l}\text { Sayur-sayuran (vegeta- } \\
\text { bles) }\end{array}$ & 1 \\
\hline Buah (fruit) & 1 \\
\hline Daging/ikan (meat/fish) & 4 \\
\hline Produk susu (milk) & 4 \\
\hline Gula (sugar) & 0,5 \\
\hline Minyak (oil) & 0,5 \\
\hline
\end{tabular}

Sumber: INDDEX Project, 2018

\section{METODE PENELITIAN}

Penelitian ini menggunakan data dari Indonesia Family Life Survey (IFLS). IFLS adalah survei sosial ekonomi dan kesehatan berkelanjutan yang dimulai sejak 1993 dengan sampel rumah tangga yang mencakup 83 persen dari keseluruhan populasi Indonesia di 13 provinsi. IFLS1 dilakukan di tahun 1993, IFLS2 di tahun 1997, IFLS3 di tahun 2000, IFLS4 di tahun 2007 dan IFLS5 di tahun 2014. Data IFLS seringkali digunakan dalam analisis dampak kebijakan bagi rumah tangga, sebagai contoh adalah analisis kebijakan beras untuk keluarga miskin (raskin) (Strauss, Witoelar \& Sikoki, 2016; Sadono, 2018; Satriawan \& Shrestha, 2018).

Variabel dependen yang digunakan mengacu pada indikator ketahanan pangan yang dianggap paling sesuai dan sederhana dalam mengukur konsumsi pangan rumah tangga, yaitu FCS (Tiwari, Skoufias \& Sherpa, 2013; Cafiero et al., 2014; INDDEX Project, 2018; Isaura, Chen \& Yang, 2018). Data dalam IFLS yang digunakan sebagai pengukuran skor FCS adalah data FM02 dan FM03. Berdasarkan data tersebut, makanan pokok adalah konsumsi nasi dan ubi; sayursayuran adalah sayuran hijau dan wortel; buah adalah konsumsi pisang, pepaya dan mangga; daging/ikan terdiri atas konsumsi daging, ikan dan telur; serta produk susu adalah konsumsi susu, keju, mentega dan sejenisnya. Skor setiap 
kelompok makanan kemudian dijumlahkan untuk didapatkan skor akhir. Penelitian ini merujuk pada penelitian Isaura et al. (2018) dalam menentukan kondisi rawan pangan, yaitu ketika skor FCS masuk kategori poor (0-21) dan borderline (21.5-35). Kondisi aman pangan adalah ketika skor FCS masuk kategori acceptable (skor FCS lebih dari 35).

Faktor-faktor sosial ekonomi yang menjadi variabel independen dalam penelitian ini merupakan replikasi dan pengembangan dari penelitian-penelitian sebelumnya. Faktor-faktor tersebut kemudian dikategorikan menjadi faktor sumber daya manusia dan faktor kualitatif (Maharjan \& Joshi, 2011). Faktor sumber daya manusia terdiri atas umur, jenis kelamin (gender), status perkawinan dan tingkat pendidikan kepala rumah tangga. Faktor-faktor tersebut secara umum ditemukan pada penelitian-penelitian sebelumnya (Rose, Gundersen \& Oliveira, 1998; Iram \& Butt, 2004; Maharjan \& Joshi, 2011; Abu \& Soom, 2016; Grobler, 2016; Mutisya, Ngware, Kabiru, \& Kandala, 2016; Ahmed et al., 2017; Mustapha, Kamaruddin \& Dewi, 2018; Abdullah et al., 2019). Dalam IFLS, data pendapatan adalah per individu anggota rumah tangga, sedangkan dalam penelitian ini, data yang dipakai adalah data rumah tangga. Dengan demikian, variabel untuk faktor ekonomi diwakili oleh data-data yang memang tersedia di tingkat rumah tangga, yaitu bidang pekerjaan kepala rumah tangga, status kepemilikan rumah, bahan bakar utama untuk memasak dan listrik rumah tangga.

Faktor kualitatif terdiri dari pekerjaan kepala rumah tangga, status kepemilikan rumah, ketersediaan toilet di dalam rumah, bahan bakar utama yang digunakan untuk memasak, ketersediaan listrik, serta ketersediaan sumber air untuk keperluan lainnya di dalam rumah. Beberapa penelitian ketahanan pangan sebelumnya melakukan analisis pada rumah tangga pertanian (Ahmed et al., 2017; Mustapha, Kamaruddin \& Dewi, 2018; Abdullah et al., 2019; Zani et al., 2019) dengan asumsi rumah tangga pertanian pada umumnya berkaitan erat dengan kemiskinan dan kerawanan pangan. Oleh karena itu, salah satu variabel dalam penelitian ini adalah pekerjaan kepala rumah tangga yang bernilai 0 apabila petani dan 1 apabila bukan. Status kepemilikan rumah/lahan merupakan variabel penentu ketahanan pangan dalam penelitian Mustapha et al. (2018) dan Rose et al. (1998). Variabel ketersediaan toilet di dalam rumah serta ketersediaan sumber air dalam rumah merupakan replikasi dari penelitian Iram \& Butt (2004), Sulemana, Bugri Anarfo, \& Quartey (2019) dan Lestari \& Sarana (2018). Hal ini didukung oleh Reddy, Rani, Cadman, Kumar, \& Reddy (2016) yang menyatakan bahwa akses ke sumber air dan akses ke fasilitas sanitasi merupakan determinan dari pemanfaatan pangan. Sulemana et al. (2019) menambahkan bahwa ketersediaan listrik dalam rumah tangga memiliki korelasi positif pada ketahanan pangan rumah tangga. Faktor tambahan lainnya adalah lokasi sebab beberapa penelitian menemukan bahwa lokasi rumah tangga (desa, kota, kondisi topografis) merupakan faktor penentu kerawanan pangan (Iram \& Butt, 2004; Maharjan \& Joshi, 2011; Abu \& Soom, 2016; Sulemana, et al., 2019)..

Berdasarkan penelitian-penelitian sebelumnya dan dengan pertimbangan ketersediaan data dalam IFLS, model dalam penelitian ini yang kemudian akan dianalisis dengan menggunakan regresi logistik adalah sebagai berikut:

$$
\mathrm{FCS}=\beta_{0}+\beta_{1} \mathrm{SDM}+\beta_{2} \mathrm{FK}+\beta_{3} \mathrm{LOK}+\mu
$$

FCS adalah variabel biner dari ketahanan pangan, $\boldsymbol{S D M}$ adalah sumber daya manusia dalam rumah tangga, $\boldsymbol{F} \boldsymbol{K}$ adalah faktor-faktor kualitatif dan $\boldsymbol{L O K}$ adalah variabel lokasi. Deskripsi dari tiap variable adalah sebagai berikut:

Tabel 3. Variabel dan Hipotesis Penelitian

\begin{tabular}{|c|c|c|}
\hline Variabel & Deskripsi & $\begin{array}{l}\text { Hipotesis pengaruh } \\
\text { variabel } \\
\text { independen }\end{array}$ \\
\hline Skor FCS & $\begin{array}{l}\text { Variabel biner. } \\
\text { Bernilai } 1 \text { bila suatu rumah tangga memiliki skor } \mathrm{FCS}>35 \text {. Bernilai } 0 \\
\text { bila suatu rumah tangga memiliki skor } \mathrm{FCS}=0-35\end{array}$ & n.a. \\
\hline
\end{tabular}




\begin{tabular}{|c|c|c|}
\hline Variabel & Deskripsi & $\begin{array}{l}\text { Hipotesis pengaruh } \\
\text { variabel } \\
\text { independen }\end{array}$ \\
\hline \multicolumn{3}{|c|}{ Sumber Daya Manusia (SDM) } \\
\hline hhhead_age & Umur kepala rumah tangga & Positif/negatif \\
\hline hhhead_gender & $\begin{array}{l}\text { Jenis kelamin kepala rumah tangga } \\
\text { Variabel biner: } 1 \text { untuk laki-laki, } 0 \text { untuk perempuan }\end{array}$ & Positif \\
\hline marstat & $\begin{array}{l}\text { Status perkawinan kepala rumah tangga } \\
\text { Variabel biner: } 1 \text { untuk menikah, } 0 \text { untuk lainnya }\end{array}$ & Positif \\
\hline hhhead_edu & $\begin{array}{l}\text { Tingkat pendidikan kepala rumah tangga } \\
\text { Variabel biner: } 1 \text { untuk SD dan sederajat, } 0 \text { untuk tidak }\end{array}$ & Positif \\
\hline \multicolumn{3}{|c|}{ Faktor-faktor kualitatif } \\
\hline hhhead_famer & $\begin{array}{l}\text { Bidang pekerjaan kepala rumah tangga } \\
\text { Variabel biner: } 1 \text { bila pekerjaan kepala rumah tangga adalah bukan } \\
\text { petani, } 0 \text { bila petani }\end{array}$ & Positif \\
\hline status_house & $\begin{array}{l}\text { Status kepemilikan rumah } \\
\text { Variabel biner: } 1 \text { bila rumah merupakan milik sendiri, } 0 \text { bila tidak }\end{array}$ & Positif \\
\hline toilet_loc & $\begin{array}{l}\text { Letak toilet rumah tangga } \\
\text { Variabel biner: } 1 \text { bila letak toilet di dalam rumah, } 0 \text { bila tidak }\end{array}$ & Positif \\
\hline stove & $\begin{array}{l}\text { Bahan bakar utama untuk memasak } \\
\text { Variabel biner: } 1 \text { bila sumber bahan bakar utama untuk memasak } \\
\text { adalah listrik atau gas, } 0 \text { bila tidak }\end{array}$ & Positif \\
\hline elect & $\begin{array}{l}\text { Listrik rumah tangga } \\
\text { Variabel biner: } 1 \text { bila rumah tangga sudah menggunakan listrik, } 0 \\
\text { bila tidak }\end{array}$ & Positif \\
\hline water_loc & $\begin{array}{l}\text { Sumber air utama rumah tangga untuk mandi dan mencuci } \\
\text { Variabel biner: } 1 \text { bila sumber air utama rumah tangga untuk mandi } \\
\text { dan mencuci berada di dalam rumah, } 0 \text { bila tidak }\end{array}$ & Positif \\
\hline \multicolumn{3}{|l|}{ Lokasi } \\
\hline region & $\begin{array}{l}\text { Lokasi rumah tangga } \\
\text { Variabel biner: } 1 \text { bila lokasi rumah tangga berada di daerah perkota- } \\
\text { an dan } 0 \text { bila tidak }\end{array}$ & Positif \\
\hline
\end{tabular}

Penentuan hipotesis pengaruh variabel independen pada variabel dependen dilakukan berdasarkan penelitian-penelitian sebelumnya, seperti variabel umur. Variabel umur dapat memiliki pengaruh positif atau negatif pada keamanan pangan. Pengaruh positif variabel ini berdasarkan pemikiran bahwa pengalaman dalam menyediakan pangan yang diperlukan dan sesuai bagi rumah tangga akan meningkat seiring dengan umur ibu atau umur kepala rumah tangga (sebagai contoh dalam Rose et al., 1998; Sulemana et al., 2019). Sebaliknya, pemikiran lain menyatakan bahwa semakin tinggi (semakin tua) umur kepala rumah tangga, semakin tidak produktif rumah tangga tersebut sehingga akan semakin rawan pangan (Abu \& Soom, 2016; Grobler, 2016).

Model regresi logistik yang digunakan adalah logit. Estimasi regresi logistik diikuti dengan tindakan pasca estimasi yaitu pendugaan parameter dengan pendekatan nilai log-likelihood serta uji kelayakan model melalui uji Pearson dan Hosmer-Lemeshow (Hendayana, 2015).

\section{HASIL DAN PEMBAHASAN}

Data IFLS terdiri dari 16.204 rumah tangga dan 50.148 individu. Keseluruhan data tersebut "dibersihkan" dengan menggunakan software Stata agar dapat mencakup variabel dependen dan keseluruhan variabel independen yang menjadi tujuan penelitian. Total sampel yang digunakan setelah dilakukan pembersihan data adalah 9.819 rumah tangga. Tabel 4 menunjukkan statistik deskriptif dari variabel-variabel yang digunakan. 
Tabel 4. Statistik Deskriptif Variabel

\begin{tabular}{llllll}
\hline Variable & Obs & Mean & Std. Dev. & Min & Max \\
\hline fs & 9819 & 0,18464 & 0,38803 & 0 & 1 \\
\hline $\begin{array}{l}\text { status_ } \\
\text { house }\end{array}$ & 9819 & 0,65475 & 0,47547 & 0 & 1 \\
\hline toilet_loc & 9819 & 0,81434 & 0,38885 & 0 & 1 \\
\hline stove & 9819 & 0,69630 & 0,45988 & 0 & 1 \\
\hline elect & 9819 & 0,99134 & 0,09264 & 0 & 1 \\
\hline water_loc & 9819 & 0,32529 & 0,46851 & 0 & 1 \\
\hline region & 9819 & 0,60149 & 0,48962 & 0 & 1 \\
\hline $\begin{array}{l}\text { hhhead_ } \\
\text { age }\end{array}$ & 9819 & 42,58275 & 14,52512 & 15 & 101 \\
\hline $\begin{array}{l}\text { hhhead_ } \\
\text { gender }\end{array}$ & 9819 & 0,89989 & 0,30016 & 0 & 1 \\
\hline $\begin{array}{l}\text { marstat } \\
\text { hhhead_ }\end{array}$ & 9819 & 0,85100 & 0,35610 & 0 & 1 \\
\hline $\begin{array}{l}\text { edu } \\
\text { hhhead_ } \\
\text { farmer }\end{array}$ & 9819 & 0,96140 & 0,19265 & 0 & 1 \\
\hline
\end{tabular}

Sumber: IFLS5, diolah

Tabel 5 memuat hasil pendugaan model regresi logistik dengan pendekatan nilai $\log$ likelihood. Hipotesis nol untuk pendugaan model regresi logistik adalah $\mathrm{H}_{0}$ : tidak ada satupun variabel independen yang secara statistik signifikan mempengaruhi variabel dependen dan hipotesis alternatifnya, yaitu $\mathrm{H}_{1}$ : minimal ada satu variabel independen yang secara statistik signifikan mempengaruhi variabel dependen. Nilai LR sebesar 219,47 dan dengan $\alpha=5 \%$, maka nilai $p$-value $<\alpha$ yang berarti bahwa minimal ada satu variabel independen yang secara statistik signifikan mempengaruhi variabel dependen.

Tabel 5. Hasil Pendugaan Parameter

\begin{tabular}{lll}
\hline Logistic regression & Number of obs & $=9819$ \\
& LR chi2(9) & $=219,47$ \\
& Prob $>$ chi2 & $=0,0000$ \\
Log likelihood $=$ & Pseudo R2 & $=0,0234$ \\
$-4587,282$ & & \\
\hline
\end{tabular}

Sumber: IFLS5, diolah

Model regresi logistik diuji kelayakannya (goodness of fit) dengan menggunakan metode Pearson dan Hosmer-Lemeshow (Tabel 6). Nilai serta $p$-value dari uji Pearson dan HosmerLemeshow masing-masing adalah 2997,52 dan 12,25 serta 0,4222 dan 0,1406 . Hipotesis nol $\left(\mathrm{H}_{0}\right)$ akan ditolak bila nilai $p$-value $<\alpha$ yang berarti bahwa model tidak sesuai dengan data. Dengan menggunakan $\alpha=0,05$, hasil dari uji Pearson dan Hosmer-Lemeshow menyatakan bahwa model logit layak digunakan.

Tabel 6. Uji Kelayakan

\begin{tabular}{lcll}
\hline Uji Pearson & & \multicolumn{2}{l}{ Uji Hosmer-Lemeshow } \\
\hline $\begin{array}{l}\text { number of } \\
\text { observations }\end{array}$ & 9819 & $\begin{array}{l}\text { number of } \\
\text { observations }\end{array}$ & 9.819 \\
\hline $\begin{array}{l}\text { number of } \\
\text { covariate pat- } \\
\text { terns }\end{array}$ & 2995 & $\begin{array}{l}\text { number of } \\
\text { groups }\end{array}$ & 10 \\
\hline $\begin{array}{l}\text { Pearson } \\
\text { chi2(3729) }\end{array}$ & 2997,52 & $\begin{array}{l}\text { Hosmer-Leme- } \\
\text { show chi2(8) }\end{array}$ & 12,25 \\
\hline Prob > chi2 & 0,4222 & Prob > chi2 & 0,1406 \\
\hline
\end{tabular}

Sumber: IFLS5, diolah

Uji parsial setiap variabel independen dalam regresi logistik dilakukan dengan uji Wald. Dalam Tabel 7, Nilai z menunjukkan hasil dari uji Wald. Terdapat delapan variabel independen yang secara statistik berpengaruh signifikan terhadap variabel dependen, yaitu: 1) keberadaan toilet dalam rumah (toilet_loc); 2) sumber bahan bakar utama untuk memasak (stove); 3 ) sumber air untuk mandi dan mencuci berada di dalam rumah (water_loc); 4) lokasi rumah tangga (region); 5) usia kepala rumah tangga (head_age); 6) status perkawinan kepala rumah tangga (marstat); 7) tingkat pendidikan kepala rumah tangga (head_edu); dan 8) jenis pekerjaan kepala rumah tangga (head_farmer). Variabel independen lainnya, yaitu kepemilikan rumah (status_house), ketersediaan listrik dalam rumah tangga (elect) serta jenis kelamin kepala rumah tangga (head gender) tidak berpengaruh nyata terhadap kondisi ketahanan pangan rumah tangga.

Tabel 7. Hasil Regresi Logistik

\begin{tabular}{lllll}
\hline Variabel & $\begin{array}{l}\text { Odds } \\
\text { Ratio }\end{array}$ & Std. Err. & $\mathbf{z}$ & $\mathbf{P}>|\mathbf{z}|$ \\
\hline $\begin{array}{l}\text { status_ } \\
\text { house }\end{array}$ & 0,96915 & 0,06283 & $-0,48$ & 0,629 \\
\hline toilet_loc & 1,71400 & 0,14202 & 6,50 & $0,000^{*}$ \\
\hline stove & 1,33889 & 0,08854 & 4,41 & $0,000^{*}$ \\
\hline elect & 1,16570 & 0,41791 & 0,43 & 0,669 \\
\hline water_loc & 1,31573 & 0,07644 & 4,72 & $0,000^{*}$ \\
\hline region & 1,30099 & 0,07945 & 4,31 & $0,000^{*}$ \\
\hline head_age & 1,00677 & 0,00217 & 3,13 & $0,002^{*}$ \\
\hline
\end{tabular}




\begin{tabular}{lllll}
\hline Variabel & $\begin{array}{l}\text { Odds } \\
\text { Ratio }\end{array}$ & Std. Err. & $\mathbf{z}$ & $\mathbf{P}>|\mathbf{z}|$ \\
\hline $\begin{array}{l}\text { head_gen- } \\
\text { der }\end{array}$ & 1,01832 & 0,10825 & 0,17 & 0,864 \\
\hline marstat & 0,80282 & 0,07403 & $-2,38$ & $0,017^{*}$ \\
\hline head_edu & 1,58717 & 0,28158 & 2,60 & $0,009^{*}$ \\
\hline $\begin{array}{l}\text { head_ } \\
\text { farmer }\end{array}$ & 1,36760 & 0,10448 & 4,10 & $0,000^{*}$ \\
\hline cons & 0,03424 & 0,01422 & $-8,13$ & $0,000^{*}$ \\
\hline
\end{tabular}

Sumber: IFLS5, diolah

Keterangan: *) signifikan pada taraf 5\%

Penafsiran hasil regresi logistik dilakukan dengan melihat nilai odds ratio. Odds dari suatu kejadian dalam penelitian ini diartikan sebagai kecenderungan aman pangan atau rawan pangan. Bila nilai odds ratio mendekati nol berarti sebuah rumah tangga cenderung rawan pangan. Lebih lanjut, nilai odds ratio lebih besar daripada satu menunjukkan bahwa pengaruh variabel independen terhadap variabel dependen adalah positif, dan demikian sebaliknya (Hendayana, 2015). Berdasarkan hasil estimasi, nilai odds ratio kurang dari satu dimiliki oleh variabel status_house, marstat dan konstanta.

Iram \& Butt (2004) menyatakan bahwa faktor-faktor lingkungan seperti akses ke sumber air dan fasilitas sanitasi di dalam rumah secara tidak langsung akan meningkatkan kapasitas penyediaan pangan rumah tangga. Badan Ketahanan Pangan (2018) pun menggarisbawahi hal ini dengan menyatakan bahwa akses terhadap air bersih memegang peranan yang penting dalam pencapaian ketahanan pangan. Nilai koefisien odds ratio dari keberadaan toilet (toilet_loc) menunjukkan bahwa rumah tangga dengan toilet di dalam rumah memiliki peluang/ probabilitas 1,71 kali lebih besar untuk tahan pangan dibandingkan rumah tangga lainnya. Di antara variabel-variabel lain yang signifikan, variabel toilet_loc memiliki nilai statistik $\mathrm{z}$ terbesar, sehingga variabel ini memiliki hubungan paling besar dalam menjelaskan karakteristik ketahanan pangan dalam rumah tangga. Variabel sumber air utama rumah tangga untuk mandi dan mencuci (water_loc) pun signifikan dengan koefisien odds ratio sebesar 1,32. Namun, hasil ini tidak sesuai dengan hasil penelitian Lestari \& Sarana (2018). Lestari \& Sarana (2018) dengan menggunakan data Survei Sosial Ekonomi Nasional (SUSENAS) tahun 2013 melakukan regresi OLS dengan asupan kalori rumah tangga sebagai variabel dependen dan infrastruktur sanitasi dan air (jenis toilet dan akses air pipa) sebagai salah satu variabel independen. Hasil regresi menunjukkan bahwa infrastruktur sanitasi dan air secara negatif memiliki pengaruh signifikan terhadap asupan kalori rumah tangga. Perbedaan hasil ini kemungkinan disebabkan oleh perbedaan data dan metodologi yang digunakan.

Rumah tangga yang menggunakan listrik dan gas sebagai bahan bakar utama memasak juga memiliki probabilitas ketahanan pangan 1,34 kali lebih besar bila dibandingkan dengan rumah tangga yang menggunakan bahan bakar lainnya, seperti minyak tanah, kayu bakar atau arang/batubara. Sementara koefisien odds ratio dari lokasi sebesar 1,3 mempunyai arti bahwa rumah tangga yang berlokasi di perkotaan akan meningkatkan probabilitas ketahanan pangan sebesar 1,3 dengan asumsi faktor lainya konstan. Hasil ini sesuai dengan penelitian Iram \& Butt (2004) dan Maharjan \& Joshi (2011) bahwa rumah tangga di perkotaan memiliki ketahanan pangan lebih tinggi daripada rumah tangga di perdesaan.

Variabel-variabel dalam faktor sumber daya manusia rumah tangga semua memiliki pengaruh signifikan pada ketahanan pangan, kecuali variabel head_gender. Sesuai dengan hasil penelitian Iram \& Butt (2004) dan Abu \& Soom (2016) yang menyatakan bahwa usia kepala keluarga memiliki peranan penting dalam penyediaan pangan yang layak, variabel usia (head_age) dalam penelitian ini juga memiliki pengaruh secara signifikan terhadap ketahanan pangan. Koefisien odds ratio dari usia kepala rumah tangga adalah sebesar 1,01.

Koefisien odds ratio dari status perkawinan (marstat) sebesar 0,80 mempunyai arti bahwa kepala rumah tangga dengan status perkawinan menikah akan meningkatkan probabilitas ketahanan pangan sebesar 0,80 kali dengan asumsi faktor lainnya konstan. Hal ini menggarisbawahi peran dari ibu rumah tangga dalam penyediaan pangan rumah tangga mengingat bahwa mayoritas kepala rumah tangga sampel adalah pria.

Koefisien odds ratio dari tingkat pendidikan kepala rumah tangga (head_edu) sebesar 1,59 
mempunyai arti bahwa kepala rumah tangga dengan tingkat pendidikan minimal sekolah dasar (SD) akan meningkatkan probabilitas ketahanan pangan rumah tangga sebesar 1,59 kali dibandingkan dengan rumah tangga dengan kepala rumah tangga yang belum pernah bersekolah. Pengaruh signifikan dari sekolah juga ditemui dalam penelitian oleh Nord (2009), Rose et al. (1998), Babatunde, Omotesho, \& Sholotan (2007) dan Tajerin et al. (2017). Kasus kerawanan pangan jarang ditemui di rumah tangga dengan kepala rumah tangga lulusan sekolah menengah umum. Hasil ini berkebalikan dengan temuan Zani et al. (2019) yang menyatakan bahwa semakin tinggi pendidikan kepala rumah tangga petani ubi kayu di Sulawesi, maka makin berkurang pengeluaran makanan. Namun, bila diartikan bahwa rumah tangga miskin adalah rumah tangga dengan sebagian besar pengeluaran dihabiskan untuk belanja makanan dan dengan demikian lebih rawan pangan (Mulyanto, 2005), maka hasil penelitian ini sesuai dengan temuan Zani et al. (2019).

Koefisien odds ratio dari jenis mata pencaharian kepala rumah tangga (head_farmer) sebesar 1,37 mempunyai arti bahwa kepala rumah tangga dengan mata pencaharian bukan petani akan meningkatkan probabilitas ketahanan pangan sebesar 1,37 kali dengan asumsi faktor lainya konstan. Hal ini kemungkinan disebabkan masih rendahnya penghasilan dan kepemilikan asset petani pada umumnya (Zani et al., 2019).

\section{KESIMPULAN DAN REKOMENDASI}

Berdasarkan hasil estimasi regresi logistik dengan menggunakan data IFLS5, faktor-faktor yang mempengaruhi frekuensi makan adalah aspek sanitasi (keberadaan toilet dan sumber air untuk mandi serta memasak terletak di dalam rumah), penggunaan bahan bakar utama untuk memasak, lokasi rumah tangga, usia kepala rumah tangga, status perkawinan kepala rumah tangga, tingkat pendidikan kepala rumah tangga, dan jenis mata pencaharian kepala rumah tangga. Hasil penelitian ini dapat memberikan gambaran mengenai dimensi sosial ekonomi yang mempengaruhi ketahanan pangan rumah tangga di Indonesia.

Hasil penelitian ini mendukung pernyataan bahwa peningkatan ketahanan pangan tidak hanya bisa dicapai dengan program-program bantuan dari pemerintah secara langsung seperti Bantuan Pangan Non Tunai Kementerian Sosial, tetapi dapat dengan beberapa cara seperti: 1) edukasi ibu rumah tangga mengingat adanya peran signifikan ibu rumah tangga dalam penyediaan pangan keluarga, 2) peningkatan edukasi masyarakat karena tingkat pendidikan mempengaruhi pola pikir masyarakat terhadap pentingnya ketersediaan pangan bagi keluarga serta 3) program-program bantuan dan pemberdayaan bagi masyarakat perdesaan pada umumnya dan bagi petani pada khususnya karena probabilitas ketahanan pangan lebih besar ditemui pada rumah tangga yang berlokasi di perkotaan dengan jenis pekerjaan kepala rumah tangga bukan petani. Dengan besarnya keterkaitan antara faktor air bersih dan sanitasi, menunjukkan bahwa penyediaan infrastruktur yang merata terutama di wilayah pedesaan menjadi sangat penting.

\section{DAFTAR PUSTAKA}

Abdullah, Zhou, D., Shah, T., Ali, S., Ahmad, W. Izhar, U. D., \& Ilyas, A. (2019) 'Factors affecting household food security in rural northern hinterland of Pakistan', Journal of the Saudi Society of Agricultural Sciences. King Saud University \& Saudi Society of Agricultural Sciences, 18(2), pp. 201-210. doi: 10.1016/j.jssas.2017.05.003.

Abu, G. A. \& Soom, A. (2016) 'Analysis of Factors Affecting Food Security in Rural and Urban Farming Households of Benue State, Nigeria', International Journal of Food and Agricultural Economics, 4(1), pp. 55-68.

Ahmed, U. I., Ying, L., Bashir, M. K., Abid, M., \& Zulfiqar, F. (2017) 'Status and determinants of small farming households' food security and role of market access in enhancing food security in rural Pakistan', PloS one, 12(10), $\mathrm{e} 0185466$.

Ariani, M. (2004) 'Penguatan Ketahanan Pangan Daerah untuk Mendukung Ketahanan Pangan Nasional', Pusat Analisis Sosial Ekonomi dan Kebijakan Pertanian, 1999(70), pp. 23-37. 
Babatunde, R. O., Omotesho, O.A. \& Sholotan, O. S. (2007) 'Socio-economics characteristics and food security status of farming households in Kwara State, north-central Nigeria', Pakistan Journal of Nutrition, pp. 49-58. doi: 10.3923/pjn.2007.49.58.

Badan Ketahanan Pangan (2018) Peta Ketahanan dan Kerentanan Pangan Indonesia (A Food Security and Vulnerability Atlas), Kementerian Pertanian. Available at: http:// bkp.pertanian.go.id/storage/app/media/ Pusat Ketersediaan/Bidang Ketersediaan/ peta-ketahanan-kerentanan-pangan-2018. pdf.

Cafiero, C., Melgar-Quinonez, H. R., Ballard, T. J., \& Kepple, A. W. (2014) 'Validity and reliability of food security measures', Annals of the New York Academy of Sciences, 1331(1), pp. 230-248. doi: 10.1111/ nyas. 12594.

Damanik, S. (2016) 'Keterkaitan Ketahanan Pangan dengan Kemiskinan Berdasarkan Implementasi Kebijakan Penanggulangan Kemiskinan di Indonesia', Economics Development Analysis Journal, 5(1), pp. 38-47. doi: 10.1016/S0301-7036(14)708624.

Dharmasena, S., Bessler, D. A. \& Todd, J. (2016) 'Complex Interactions of Socioeconomic, Demographic and Geographic Factors Affecting Household Food Purchase and Acquisition Decisions in the United States', Agricultural \& Applied Economics Association Annual Meeting, pp. 1-10.

FAO (2017) The Food Insecurity Experience Scale: Measuring food insecurity through people's experiences. Food and Agriculture Organization. Available at: http://www.fao. org/3/a-i7835e.pdf(Accessed: 27 September 2020).

Grobler, W. C. J. (2016) 'Perceptions of Poverty: A Study of Food Secure and Food Insecure Households in an Urban Area in South Africa', Procedia Economics and Finance. Elsevier B.V., 35(October 2015), pp. 224231. doi: 10.1016/s2212-5671(16)00028-9.
Gundersen, C., Kreider, B. \& Pepper, J. (2011) 'The Economics of Food Insecurity in the United States', Applied Economic Perspectives and Policy, 33(3), pp. 281-303. doi: 10.1093/aepp/ppr022.

Hendayana, R. (2015) 'Penerapan Metode Regresi Logistik Dalam Menganalisis Adopsi Teknologi Pertanian', Informatika Pertanian, 22(1), p. 1. doi: 10.21082/ ip.v22n1.2013.p1-9.

INDDEX Project (2018) Data4Diets: Building blocks for diet-related food security analysis. Boston. Available at: https://inddex. nutrition.tufts.edu/data4diets (Accessed: 27 September 2020).

Iram, U. \& Butt, M. S. (2004) 'Determinants of household food security: An empirical analysis for Pakistan', International Journal of Social Economics, 31(8), pp. 753-766. doi: http://dx.doi.org/10.1108/MRR-092015-0216.

Isaura, E. R., Chen, Y. C. \& Yang, S. H. (2018) 'The association of food consumption scores, body shape index, and hypertension in a seven-year follow-up among Indonesian adults: A longitudinal study', International Journal of Environmental Research and Public Health, 15(1). doi: 10.3390/ ijerph15010175.

Lestari, E. \& Sarana, J. (2018) 'Determinants of household's food and nutrition security in Indonesia', Jurnal Ekonomi dan Pembangunan, 26(2), pp. 105-115.

Maharjan, K. L. \& Joshi, N. P. (2011) 'Determinants of household food security in Nepal: A binary logistic regression analysis', Journal of Mountain Science, 8(3), pp. 403-413. doi: 10.1007/s11629-011-2001-2.

Mulyanto (2005) Kemiskinan dan Kebutuhan Pokok. Jakarta: Rajawali.

Mustapha, M., Kamaruddin, R. B. \& Dewi, S. (2018) 'Factors affecting rural households food security status in Kano, Nigeria', International Journal of Management Research \& Review, 8(9), pp. 1-19. Available at: www.ijmrr.com. 
Mutisya, M., Ngware, M. W., Kabiru, C. W., \& Kandala, N. B. (2016) 'The effect of education on household food security in two informal urban settlements in Kenya: a longitudinal analysis', Food Security. Food Security, 8(4), pp. 743-756. doi: 10.1007/ s12571-016-0589-3.

Nord, M. (2009) 'Food Insecurity in Households With Children: Prevalence, Severity, and Household Characteristics', Economic Information Bulletin, 56.

Pinstrup-Andersen, P. (2009) 'Food security: definition and measurement', Food Security, 1(1), pp. 5-7. doi: 10.1007/s12571-0080002-y.

Radimer, K. L. (2002) 'Measurement of household food security in the USA and other industrialised countries', Public Health Nutrition, 5(6a), pp. 859-864. doi: $10.1079 / \mathrm{phn} 2002385$.

Reddy, A. A., Rani, C. R., Cadman, T., Kumar, S. N., \& Reddy, A. N. (2016) 'Towards sustainable indicators of food and nutritional outcomes in India', World Journal of Science, Technology and Sustainable Development, 13(2), pp. 128-142. doi: 10.1108/wjstsd-10-2015-0049.

Rose, D., Gundersen, C. \& Oliveira, V. (1998) 'Socio-economic determinants of food insecurity in the United States: evidence from the SIPP adn CSFII Data Sets', Food and Rural Economics Division, Economic Research Service, U.S. Department of Agriculture Technical Bulletin, (1869), p. 20. Available at: http://www.ers.usda.gov/ publications/TB1869/tb1869.pdf.

Sadono, E. D. (2018) 'Impact Evaluation of Raskin Program using Matching Method: Case of IFLS 5', Jejak (Jurnal Ekonomi dan Kebijakan), 11(1), pp. 207-223. doi: 10.15294/jejak.v11i1.9192.

Satriawan, E. \& Shrestha, R. (2018) 'Mistargeting and Regressive Take Up of the Indonesian Rice Subsidy Program', Asian Economic Journal, 32(4), pp. 387-415. doi: 10.1111/ asej.12164.
Smith, L. C. \& Haddad, L. (2000) 'Overcoming Child Malnutrition in Developing Countries - Past Achievements and Future Choices Acknowledgments', International Food Policy Research Institute, p. 73.

Strauss, J., Witoelar, F. \& Sikoki, B. (2016) The Fifth Wave of the Indonesia Family Life Survey: Overview and Field Report: Volume 1, WR-1143/1-NIA/NICHD. doi: 10.7249/ wr1143.1.

Sulemana, I., Bugri Anarfo, E. \& Quartey, P. (2019) 'International remittances and household food security in Sub-Saharan Africa', Migration and Development. Routledge, 8(2), pp. 264-280. doi: 10.1080/21632324.2018.1560926.

Tajerin, T., Sastrawidjaja, S. \& Yusuf, R. (2017) 'Tingkat kesejahteraan dan ketahanan pangan rumahtangga nelayan miskin: Studi kasus di Kelurahan Marunda Baru, DKI Jakarta dan Desa Tanjung Pasir, Banten', Jurnal Sosial Ekonomi Kelautan dan Perikanan, 6(1), p. 83. doi: 10.15578/jsekp. v6i1.5757.

The Economist Group (2018) 'Global Food Security Index 2018: Build resiliance in the face of rising food-security risks', The Economist Group. Available at: http:// foodsecurityindex.eiu.com/Country/ Details\#Germany.

Tiwari, S., Skoufias, E. \& Sherpa, M. (2013) 'Shorter, cheaper, quicker, better: Linking measures of household food security to nutritional outcomes in Bangladesh, Nepal, Pakistan, Uganda, and Tanzania', A World Bank Policy Research Working Paper, 6584.

Vhurumuku, E. (2014) 'Food Security Indicators Elliot Vhurumuku Senior Regional VAM Advisor WFP East and Central Africa Bureau, Nairobi For the Integrating Nutrition and Food Security Programming for Emergency response workshop', in Integrating Nutrition and Food Security Programming for Emergency Response Workshop. Available at: http://www.fao.org/fileadmin/user_ upload/food-security-capacity-building/ docs/Nutrition/NairobiWorkshop/5. WFP_IndicatorsFSandNutIntegration.pdf. 
Wolfe, W. S. \& Frongillo, E. A. (2001) 'Building household food-security measurement tools from the ground up', Food and Nutrition Bulletin, 22(1), pp. 5-12. doi: $10.1177 / 156482650102200102$.

Zani, M., Saediman, H., Abdullah, S., Daud, L., \& Yunus, L. (2019) 'Determinants of household food expenditure in a cassava growing village in southeast Sulawesi', Academic Journal of Interdisciplinary Studies, 8(3), pp. 302-310. doi: 10.36941/ ajis-2019-0028. 
